The attitudes of bilingual Arab immigrant children to their languages

\author{
Alsahafi, Morad $\Sigma \Delta$ \\ King Abdulaziz University, Saudi Arabia (m.alsahafi@gmail.com) \\ Received: 29 January 2018 \\ Available Online: 5 April 2018 \\ Revised: 1 March 2018 \\ DOI: 10.5861 ijrse.2018.3005
}

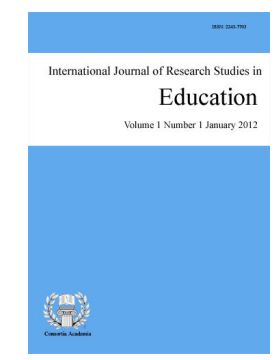

Accepted: 26 March 2018

ISSN: 2243-7703 Online ISSN: 2243-7711

OPEN ACCESS

\title{
Abstract
}

This paper seeks to explore how Arab immigrant children view Arabic, English and Arabic-English bilingualism. Data for the study were collected through narrative interviews and observations with a group of 10 Arabic speaking immigrant children living with their parents in Auckland, New Zealand. Analysis of the data indicated that the children had positive attitudes towards Arabic, English, and bilingualism in Arabic and English. Despite their awareness of their inferior Arabic skills and preference for using English, Arabic maintenance was regarded as important for maintaining contacts with parents and extended families overseas and preserving religious identity. The children also held positive attitudes towards English and bilingualism. The majority of them said that they found English to be easier to learn and use than Arabic in their English-dominant environment. The importance of English was reinforced by such instrumental reasons as school success and communicating with members of the wider community. Similarly, the children had positive attitudes towards being bilingual in Arabic and English, and articulated a number of practical advantages such as the ability to communicate more widely and elevated self-esteem.

Keywords: bilingualism; immigrant children; language attitudes; language maintenance 


\section{The attitudes of bilingual Arab immigrant children to their languages}

\section{Introduction}

A typical pattern for minority immigrant families arriving in their new places of relocation is to find themselves members of a minority group interacting with a more powerful majority group which is culturally and linguistically different (Clyne, 2003; Fishman, 1989). In this regard, many immigrant children find themselves living with two languages in the host country: a minority language spoken by their parents who strive to pass it on to them through the use of a variety of strategies and a majority language in which they are heavily immersed in its natural and dominant environment. Indeed, the dilemma facing immigrant minority children, as described by Fillmore (2000) and others may be viewed as less a problem of learning the dominant mainstream language than of home language loss. In this connection, language attitudes appear to be an important factor influencing "language restoration, preservation, decay or death" (Baker, 1992, p. 9). The following subsections provide an overview of relevant previous research pertinent to (1) language attitudes and heritage language learning, (2) subjective ethnolinguistic vitality, and (3) the influence of language attitudes on heritage language maintenance.

\subsection{Attitudes and heritage language learning}

Language attitudes can be defined as the feelings and beliefs people hold about their own language and the language(s) spoken by others (Crystal, 1992). In bilingual contexts, Myers-Scotton (2005) defined language attitudes as subjective evaluations of both languages and their speakers, whether the attitudes are held by individual speakers or by groups. Research has shown that language attitudes are important agents for language learning in general, and for heritage language learning in multilingual contexts in particular where maintaining a stable active bilingualism in the minority/heritage language and the dominant and more powerful language of the host country is difficult to achieve. Language attitudes towards a particular language(s) can be positive or negative and consequently language attitudes become important in determining language learning motivation and ultimate success.

In his influential article, orientations in language planning, Ruiz (1984) set forth three useful fundamental orientations towards language and its role in society: Language-as-problem, language-as-right, and language-asresource (see Hult \& Hornberger, 2016). According to Ruiz,

Orientations are related to language attitudes in that they constitute the framework in which attitudes are formed: they help to delimit the range of acceptable attitudes towards language, and to make certain attitudes legitimate. In short, orientations determine what is thinkable about language in society (1984, p. 16).

A language-as-a-problem orientation views language as a social and linguistic problem. For example, for many decades in the US multilingual context, this orientation aimed for the linguistic assimilation of heritage language learners through the implementation of transitional bilingual programs. The language as right orientation emphasizes the right of linguistic minority students to receive education in their mother tongue besides learning the dominant language. Ruiz's most desirable orientation, language as resource, promotes linguistic diversity in multilingual contexts. As pointed out by Ruiz,

A closer look at the idea of language-as-resource could reveal some promise for alleviating some of the conflicts emerging out of the other two orientations: it can have a direct impact on enhancing the language status of subordinate languages; it can help ease tensions between majority and minority communities; it can serve as a more consistent way of viewing the role of non-English languages in U.S. society; and it highlights the importance of cooperative language 
planning (pp. 25-26).

Research evidence has been growing in favor of the cognitive, linguistic and social advantages of bilingualism on children (see Bialystok, 2001; Cummins, 1996). It is also important not to overlook the potential economic benefits of bilingualism in the labor market in an increasingly multilingual and globalized world. These factors might jointly account for the increasing desire among minority-language families to pass their heritage language down to their children and consequently to raise their children bilingually. It is to be noted, however, that heritage language learning is not an all or nothing matter. Different heritage language learners in different contact settings can achieve different degrees of success in heritage language learning. In this connection, researchers have identified a number of factors as influencing heritage language learning outcomes. Table 1 lists the main variables mentioned in two studies (Borland, 2006; Tuominen, 1999). The table demonstrates the complexity of the process of heritage language learning and the interrelatedness of the factors involved.

\section{Table 1}

Factors influencing heritage language learning and transmission

\begin{tabular}{lc}
\hline \multicolumn{1}{c}{ Tuominen (1999) } & Borland (2006) \\
\hline - Parental language strategies & - Facilitating factors: \\
e.g. language use, child's L1 formal & a. opportunities for diasporic engagement \\
learning, & b. supportive governmental policies \\
- Visits to the homeland & - Motivating factors: \\
- Parents' education & a. desire for L1 use within the family \\
- Possibilities of out-of-home L1 input & b. desire to maintain strong familial ties with \\
- Socioeconomic status & the homeland \\
- Gender of the parent & c. positive attitudes towards bilingualism \\
- Child's personality traits & and formal language learning \\
e.g. child's reaction to parent's efforts &
\end{tabular}

As shown above, these studies, among many others, stress the importance of such environmental factors as parental language attitudes and strategies in children's heritage language development and intergenerational transmission. De Houwer (1998) proposed a three-tiered framework to explain the process through which parents' language attitudes influence minority children's bilingual language learning (see Figure 1). As shown in the figure, parental language attitudes affect their patterns of language use and choice in addressing their children, which in turn affect the dynamics of bilingual language learning in children. The Figure shows bidirectional arrows which demonstrate the complex relationships between these three levels. The author contends that, in both monolingual and bilingual settings, children's linguistic environments are generally shaped by the attitudes and beliefs of people who create these environments.

Figure 1. The relationship between parental attitudes and children's bilingual language development (Adopted from De Houwer,

1998).
PARENTAL BELIFS AND ATTITUDES

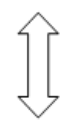

PARENTAL LINGUISTIC CHOICES AND INTERACTION STRATEGIES

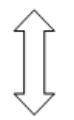

CHILDREN'S LANGUAGE DEVELOPMENT

\subsection{Subjective Ethnolinguistic Vitality}

Ethnolinguistic vitality represents a useful concept when analyzing language behavior and language attitudes of linguistic minorities. Based on Tajfel's (1974) theory of intergroup relations and Giles' (1973) theory of speech accommodation, Giles, Bourhis, and Taylor (1977) proposed a model of ethnolinguistic vitality which 
Alsahafi, M.

they define as "that which makes a group likely to behave as a distinctive and active collective entity in intergroup situations" (p. 308). Giles et al. proposed a three-factor model of ethnolinguistic vitality containing a number of structural variables responsible for establishing the vitality of an ethnolinguistic group. According to this model, an ethnolinguistic group with high vitality is more likely to enjoy a high degree of distinctiveness in multilingual settings and thus such a group is more qualified to maintain its language and cultural traits. Conversely, a group with low ethnolinguistic vitality is less likely to maintain its language and cultural practices as a distinctive collective group.

Giles et al. (1977) identified three classes of ethnolinguistic vitality factors affecting ethnic group members in intergroup situations. These are status, demographic and institutional support factors. Status variables include such components as the economic, social and language status of the ethnolinguistic group. Demographic variables concern both the number and geographical distribution of ethnolinguistic group members. Other variables included under the umbrella of demography are the group's rates of birth, mixed marriages, immigration, and emigration patterns. Institutional support factors refer to how well a minority group and its language are formally represented in a variety of institutional domains including the mass media, education, governmental departments, industry, religion, and culture. According to Giles et al., these three classes of sociological (collective) factors (status, demographic, institutional support) collectively make up the vitality of ethnolinguistic collectivities.

Beside the objective component of ethnolinguistic vitality theory, there is also another complementary subjective component proposed by Bourhis, Giles, and Rosenthal (see also Allard and Landry, 1992). Bourhis et al. (1981) constructed a Subjective Ethnolinguistic Vitality Questionnaire (SEVQ) in order to measure group members' attitudes and perceptions of their own and out-groups' ethnolinguistic vitality. Thus, this measure is concerned with how speakers perceive the vitality of their language.

Allard and Landry (1992, p. 172) propose that "a group's subjective assessment of its relative position on the variables affecting EV [ethnolinguistic vitality] may be as important in determining its inter-ethnic behaviors as its more objective position on these variables." They also maintain that group members' perceptions and beliefs of the ethnolinguistic vitality of their ethnic group influence their attitudes towards home language use and maintenance. In a study conducted in the Eastern Canadian bilingual context, Allard and Landry (1992) found a strong relationship between the objective ethnolinguistic vitality of their studied communities and the subjective ethnolinguistic vitality of the members of those communities. They also found that group members' ethnolinguistic vitality beliefs are formed in their social networks of linguistic contacts.

To sum up, the theory of ethnolinguistic vitality as proposed by Giles et al. represents a social-psychological approach to the investigation of language behavior of minority groups in multilingual and multicultural contexts and has proven to be a useful model through which vitality factors operating in favor or not of bi/multilingual language development can be investigated (Atkinson, 2000; Yagmur \& Kroon, 2006). Based on both objective and perceived ethnolinguistic vitality, it can be predicted that mother tongues of minority groups with high vitality have a strong probability of being maintained, while low vitality groups are most likely to go through linguistic assimilation by gradually abandoning their mother tongue and shift to the majority language.

\subsection{Attitudes and heritage language maintenance}

The term language maintenance refers to the situation when a minority group "continue to use their language in some or all spheres of life despite competition with the dominant or majority language to become the main/sole language in these spheres" (Pauwels 2004, p.719). The other side of the coin (i.e., language shift) is a gradual process that takes place when a speech community gives up its mother tongue (partially or completely) in favor of another language (usually the majority language). Generally, previous research on immigrant minority languages has found language shift to be more common than language maintenance (Baker, 2006; Fishman, 1991; Taft \& Cahill, 1989; Zhang, 2004). This process of language shift influences the 
intergenerational transmission of the immigrant language, leading, in many cases within the course of three generations, to monolingualism in the majority language (see Fishman, 1972). Therefore, the transmission and maintenance of the minority heritage language, one of the most obvious markers of ethnic and cultural identity, becomes one of the major challenges faced by immigrant families in the host country (Alsahafi, 2018; Fishman, 1991; Tannenbaum \& Howie, 2002).

As previously mentioned, it is a widely held belief that language attitudes play an important role in either supporting or impeding heritage language learning and development (Baker, 1992; Barkhuizen, 2006; García, 2003; Gibbons \& Ramirez, 2004; Holmes et al., 1993). For instance, some minority language parents might encourage their children to shift to the majority language in the new country in order to receive the social reward gained as a result of the assimilation in the new society. On the contrary, other parents might develop positive attitudes towards their home language and its culture and therefore choose to shoulder the burden of its maintenance and intergenerational transmission. When making such language related decisions, immigrant parents seem to be guided and motivated by their own language perceptions and attitudes. Therefore, immigrant families' language attitudes play an important role on immigrant children's home language future status (Budiyana, 2017; Zhang, 2004).

In their study of language maintenance and shift among New Zealand immigrant communities, Holmes et al (1993) identified the 'positive attitudes to the home language and a high value placed on it in relation to ethnic identity' as one of the factors that encourage language maintenance. Alsahafi (2015) explored the role of Arabic-speaking immigrant fathers in heritage language maintenance and reported that all father participants held positive attitudes towards heritage language maintenance. They reported seeking opportunities for additive rather than subtractive bilingualism among their children. According to them, learning English should not necessarily mean losing Arabic among their children. Taft and Cahill (1989) investigated patterns of language use, proficiency and attitudes among a group of Arabic speaking immigrant children in Melbourne and found language attitudes to be one the factors affecting children's overall Arabic language competence. Clyne and Kipp (1999) investigated language maintenance among Arabic-speaking immigrants in Australia and found that the attitudes towards Arabic were positive by most of their participants who demonstrated high support for its maintenance. However, such support was slightly weaker amongst their younger participants. Likewise, Budiyana (2017) explored patterns of language attitudes among Chinese students' parents and found that despite their weak proficiency in Chinese, these parents showed positive attitudes towards their heritage language maintenance and development among their children.

It should be noted, however, that positive language attitudes alone are not enough to ensure heritage language development and maintenance (Nguyen \& Hamid, 2016). For example, Choi (2003) examined language attitudes of parents and students towards the two official languages of Paraguay, Spanish and Guaraní, and found that the relationship between language attitudes and language usage is rather inconsistent in the sense that patterns of Guaraní language use do not reflect the positive attitudes of the participants towards this language. Thus, immigrants' positive attitudes need the support of both their local community and government institutions in order to increase language vitality and consequently enhance the process of home language maintenance (see, for example, Nagpal \& Nicoladis, 2010).

Clearly, an understanding of immigrant children's attitudes towards their languages, as well as towards bilingualism is important for a greater understanding of the complex process of language maintenance and transmission among immigrant minority families. In this connection, immigrant children's language attitudes and responses to parental language maintenance efforts are vital to achieving successful outcomes for home language maintenance. As Schwartz suggests, children's reports about their attitudes towards the home language "may be considered an indicator of the effectiveness" of their parents' home language maintenance strategies (2008, p. 415). Nevertheless, studies on immigrant children's attitudes are relatively scarce. The current study seeks to explore Arab immigrant children's language attitudes towards Arabic, English and Arabic-English bilingualism. 


\section{Methodology}

Setting - New Zealand represents a multicultural environment in which a large number of immigrant groups live. As an immigrant language in New Zealand, Arabic is spoken as a first language by 10746 in 2013 (Statistics New Zealand, 2013). These Arabic speakers come from various countries of the Arab world with the majority originating from Lebanon, Egypt, Morocco, Iraq, Algeria, Tunisia, Jordan and Syria. Although Arabic speaking immigrants have settled all over New Zealand, most have chosen to live in Auckland, New Zealand's largest and most multicultural city.

Participants - Ten Arabic-speaking immigrant children residing in Auckland with their parents participated in this study. Social networking was used to identify and recruit the participants. Two of the children are New Zeeland-born and the other eight children immigrated to New Zealand with their families from different Arab states including Jordan, Iraq, Syria, Tunisia and Morocco (see Table 2). The length of residence of these children ranged between 4 and 13 years with an average of nearly 9 years of residency in New Zealand.

Table 2

Details of child participants

\begin{tabular}{llcc}
\hline \multicolumn{1}{c}{ Participants } & \multicolumn{1}{c}{ Country of origin } & Age (years) & $\begin{array}{c}\text { Length of stay } \\
\text { in New Zealand (years) }\end{array}$ \\
\hline Layla & Jordan & 9 & 4 \\
Hatem & Syria & 9 & 12 \\
Esam & Iraq & 12 & 11 \\
Aisha & Morocco & 13 & 13 \\
Abdullah & Tunisia & 14 & 12 \\
Huda & Tunisia & 12 & 9 \\
Badr & Jordan & 8 & 4 \\
Khaled & Syria & 11 & 7 \\
Basmah & Iraq & 10 & 10 \\
Reem & Jordan & 13 & 6 \\
\hline
\end{tabular}

Note. All children's names are pseudonyms.

Data collection and analysis - Participant information sheets providing participants with clear information about the purpose of the study, the extent of their participation and anonymity were issued to the parents of the children and the children themselves. Before the interviews commenced, informed assent was given by all of the child participants, in addition to their parents' prior consent. Data were collected by using narrative interviews in order to encourage the children to give voice to their views and language related experiences (Chase, 1995). Each of the 10 children was audio-recorded during a narrative interview. The interviews aimed to explore children's views and attitudes towards Arabic (L1), English (L2) and bilingualism. Interviews were conducted either in Arabic or English, depending on their preference. Nine of the children chose English. On the average, each interview lasted about 30 to 40 minutes. In addition, observation in the Arabic-speaking community was conducted during the data collection process. Qualitative content analysis was used to analyze the interview transcripts (Miles \& Huberman, 1994).

\section{Findings}

This section aims to explore the children's language attitudes towards Arabic, English and Arabic-English bilingualism.

\subsection{Attitudes towards Arabic}

One of the interview questions asked the children which term they used to refer to the languages they spoke. Nine of them described Arabic by using such terms as "first language," "main language" and "original language" while English was mainly referred to as "second language." The following interview excerpts illustrate these 
The attitudes of bilingual Arab immigrant children to their languages

descriptions and illuminate some of the children's attitudes towards their languages:

Reem: Arabic is my first language because I learned it first. And I need Arabic to read the Qur'an.

Badr: Arabic is the language that really belongs to me. And it isn't English because I didn't learn it in Jordan.

Huda: [Arabic] is my original language but there are a lot of things that you cannot talk about in Arabic but you can in English. Because it is more easier in English than in Arabic.

Abdullah: $\quad$ Arabic has been my first language since I was born. I use Arabic mostly at home. But when I visited Tunisia it was all Arabic at home, at the shopping mall. Arabic is the main language because of my background...English is my second language. It is easier to use because I live in a country like New Zealand. But still I regard it as my second language.

These excerpts highlight some of the children's explanations for the descriptions they gave of their languages, including order of acquisition, i.e. because Arabic was acquired first, their Arab background and country of origin and Arabic's association with religion. Some of the children's comments revealed their awareness of their inferior first/original language proficiency. For example, Huda's seemed to associate her description of Arabic as the "original language" with a supposed higher level of Arabic proficiency. Her description of her languages therefore seemed to immediately remind her of her inferior Arabic skills and preference for English. For this reason, she followed her description of Arabic as the "original language" with the word "but" which may indicate a sense of unease regarding her description of Arabic. She further concluded her turn by providing what she thought was the reason for her preference for English, i.e. ease of use. Likewise, Abdullah's description of his languages as "first" and "second" seemed to trigger a similar feeling of unease because it was English "the second language" that was easier for him to use. He then justified this perceived ease in using his second language by referring to the English-dominant environment where he lived, "because I live in a country like New Zealand." Abdullah concluded his response by further confirming the status of English as his second language.

Like Huda and Abdullah, most of the children reported that English was easier to learn than Arabic. These children attributed this ease of using and learning English to the English-dominant environment where they lived. For example, when asked why she thought English was easier to learn than Arabic, Layla replied,

Because when you speak, it doesn't have like... I don't know. I think it's easier. I think I'll like Arabic if I go to Jordan. It is the way of the country. Like if you go to China you should speak Chinese and there I think Chinese is easier than English and Jordanian [Arabic].

Layla's comment highlights the importance of environmental factors in the process of language acquisition and maintenance. However, later in her interview, Layla expressed recognition of a need to learn Arabic despite an awareness of the difficulty ahead: "Arabic is harder. I know I need to learn it but it's really hard." To this, Reem added another reason: "Arabic is a language which is a very very big language; huge. It's got everything. I don't think English is that big". However, not all of the children seemed to agree with this view. Aisha, among two other children, considered English to be more difficult to learn than Arabic:

Like, they don't have a rule. For example, there isn't a rule like for " $p h$ " sounds like "f"; so when to use "ph" and when to use "f". But in Arabic, there are some rules that you can follow. And yeah basically this is it.

Aisha's comment demonstrates her bilingual ability to compare and contrast aspects of her two languages. In particular, Aisha was aware of the different degrees of correspondence between spelling and pronunciation in Arabic and English. Her view is supported by Ryding (2005), who points out that word structure and spelling are very systematic in Arabic and that there is a good fit between Arabic pronunciation and Arabic spelling. 
In general, the children showed positive attitudes towards the Arabic language. In their interviews, they tended to stress primarily the religious aspect of knowing Arabic, i.e. to perform daily prayers and to access and understand the Qur'an. Huda said, for example, "Arabic is really important because it is the language of the Qur'an, yeah and the language of the prophet." Likewise, Esam, who was the only child who described English as his first language, wanted to maintain his Arabic skills in order to be able to read the Qur' an more fluently:

So I can read Qur'an easier. When I didn't use to know Arabic I used to read Qur'an really hard. When I went to Egypt I learned ten sections [parts of the Qur'an] because I learned Arabic over there. I learned ten sections really very fast and now I can read very fast.

Besides its importance and status as the language of Islam, some children articulated other reasons why Arabic is important. For example, Khaled stated that he wanted to learn and retain Arabic in order to maintain contact with his family "to talk with my family." Aisha indicated that she needed Arabic to keep contact with her extended family in the home country: "Because most of my family in Morocco speaks Arabic more than they speak English and I cannot speak to them in English on the phone." More specifically, Huda reported that Arabic was important to maintain contact with her grandparents overseas: "I find it kind of easy to speak to them in Tunisian dialogue. Some words I need to look for them before I say them; I need to think about them." Clearly, such overseas phone calls stimulated children's spoken Arabic lexical retrieval and consequently supported language maintenance.

In addition, a potential return to the homeland was mentioned as another reason for the importance of home language maintenance. Layla said, for example,

And if I go back to Jordan and I don't know how to speak Arabic at all, I'll get really nervous. And when I go to school, nobody will understand me if I don't know how to speak Arabic because I'll be talking in English. So the girls will say, "Umm, what is she saying?"

The children's responses to the open question "how do you feel about Arab children who cannot speak Arabic?" reflected the importance they attached to their home language. Their responses commonly included such terms as "sad" and "sorry." For example, Aisha described her feelings as follows: "I feel sorry for them. It's actually their parents' fault. If their parents know how to speak Arabic, then they should teach them." When asked if it was always the parents' fault, she further explained, "Yes, unless if the children don't want to learn." Esam described a similar feeling, "kind of sad because they can only speak to English people." Similarly, Huda stated that she felt "sorry and hurt" because by "losing Arabic they lost other things. They lost a part of their life if you know what I mean."

Finally, Abdullah, a 14-year-old advocate of home language maintenance and bilingualism, shared his experience and offered those Arab children who have lost their Arabic the following advice (and warning):

I really feel sorry for them. I encourage them to learn more about Arabic. I say to them, "If you are Arab, you need Arabic. Do not say that, 'Oh, I can live with English.' No, no, that's a wrong idea. You have to learn English and Arabic always 50/50. When I was younger, I used to think that Arabic is not important. But when you get to my age, you think more, no, I need Arabic you know. But when you're younger you don't care and you think no I don't wanna learn Arabic. But when you get to my age you're going to regret it."

In addition to talking specifically about their attitudes towards Arabic and its maintenance, the children also spoke specifically about their attitudes towards English as well as about their feelings about being bilingual. In the next section, the children's experiences of being bilingual and feeling bilingual are portrayed trough their own voices. 


\subsection{Attitudes towards English and bilingualism}

This section explores the children's attitudes towards English and bilingualism in Arabic and English. The findings revealed that all the children in this study had positive attitudes towards the English language. As noted in the previous section, seven of the children indicated that they found English to be easier to learn and use than Arabic in the New Zealand English-dominant environment. In addition, three of them (Layla, Aisha, Reem) expressed more liking for English than Arabic mainly because they perceived it to be easier to learn and use. This is clearly apparent in the following excerpt from Aisha's interview: "I can speak it like more easily. And if I get English homework I don't really want to mind about the language like what does this word mean? I don't need to worry about what the task is."

One of the interview questions asked the children if it was important for them to learn English. They all expressed the view that it was important for a variety of mainly instrumental reasons, including school success, obtaining a job and communication with members of the wider community (e.g. teachers and peers at school). For example, Aisha expressed the necessity to use English at school, "You need to learn English to do well at school and graduate. If you do not know English, how can you deal with your kiwi friends and teachers at the school?" For Reem, the necessity to use English did not only apply to the school context, but to everywhere in New Zealand: "The place, you need English because you're in New Zealand. You need English publicly, at school, shopping centre, basically like everywhere." Furthermore, Khaled emphasized the international importance and utility of English: "because lots of people talk English all over the world. So when you know English you can speak to them and understand them." To these, Huda added another instrumental reason for the importance of English, i.e. to obtain a job: "English is important because if you want to find a job you will need English." Thus, the children seemed to recognize both the local and international importance of English.

As far as attitudes to bilingualism are concerned, the children showed favorable attitudes towards being bilingual in Arabic and English. When asked how they felt about knowing two languages, the children reported a variety of pro-bilingualism views. Their responses included such expressions as: "lucky", "happy", "good" and "proud." Moreover, the children's responses highlighted their perceptions of the practical advantages of being Arabic-English bilinguals. Huda said, for example, "I feel happy because this gives me more advantages."

Some of the children were more specific in their responses and outlined some of these advantages. Esam, for example, referred to wider communication ability as the main advantage of being bilingual: "I can speak English with English people and I can speak Arabic with Arab people. So it's like I have two languages and I have two mouths!" Layla indicated that being bilingual made her feel happy and raised her self-esteem:

Really happy because if I go back to Jordan, my friends, cousins and aunties will say, "Oh, you know how to speak two languages now! Oh!” And here at the school, my friends say, "Oh, you know two languages! Can you teach me that language? Can you teach me that language?"

As is evident in this excerpt, knowing two languages boosted Layla's self-esteem not only "here" in New Zealand as she had already experienced among her monolingual peers, but also when visiting "Jordan" (the home country) as she anticipated. In both contexts, Layla's high self-esteem seemed to be mediated by feeling good about her bilingual ability. Abdullah reported that he felt lucky to be Arabic-English bilingual because of the international importance of both languages. He further argued that knowing Arabic and English is important for his identity:

I feel lucky actually because Arabic and English are two very very important languages for any Muslim. I feel I feel it's good it's good to learn two languages. The important thing is that you need to cope with learning 50/50. You need to learn a little bit of Arabic and a little bit of English you know.

In his comment above, Abdullah, a proficient Arabic-English bilingual speaker himself, emphasized the 
Alsahafi, M.

importance of language balance in bilingual development and he seemed to be aware of the difficulty involved in maintaining stable additive bilingualism in such an English-speaking country as New Zealand.

\section{Concluding remarks}

This study examined how the children viewed their languages and bilingualism. In general, the voices of these children suggest that they had positive attitudes towards Arabic, English, and bilingualism in Arabic and English. Despite their awareness of their inferior Arabic skills and preference for using English, nine of the study's child participants described Arabic as the "first," "main," or "original" language. Arabic maintenance was regarded as important for maintaining contacts with parents and extended families overseas and preserving religious identity through reading the Qur'an and performing daily prayers.

The children also held positive attitudes towards English and bilingualism. The majority of them said that they found English to be easier to learn and use than Arabic in their English-dominant environment. The importance of English was reinforced by such instrumental reasons as school success, communicating with members of the wider community and future job opportunities. Similarly, the children had positive attitudes towards being bilingual in Arabic and English and articulated a number of practical advantages such as the ability to communicate more widely and elevated self-esteem.

The results of this study further illustrate that children's patterns of language use and preference do not seem to reflect their positive attitudes towards Arabic and its maintenance. Children views concerning perceived difficulty of learning and using Arabic support their observed patterns of language proficiency and preference for English. As can be seen in many immigrant multilingual contexts, language use is associated with two contrasting domains: a minority mother-tongue with more intimate settings such as the immigrant family and the ethnic minority community on the one hand, and an official or majority language with more formal settings such as mainstream education and the wider community, on the other. Lack of exposure or opportunity to use Arabic (e.g. Arabic local television, print media, ethnic-run businesses) seem to hinder children's Arabic language development and consequently lead to this kind of inconsistency between children's positive attitudes towards Arabic and their reported patterns of language use and preference.

Clearly, the challenge faces immigrant minority-language families in the host country is to raise their children as additive bilinguals in the minority and majority language. Both majority and minority language serve different complementary functions in the host society and therefore immigrant families' awareness of and attitudes to such language functions influence their family language policy decision making as well as their child-rearing practices (Barkhuizen, 2006). On the one hand, it is essential for children to develop skills in the mainstream language for success in education and employment. On the other hand, maintaining normal native-language development in the ethnic tongue is also important for the promotion of ethnic identity, family cohesion and intergenerational relationships. It should be noted, though, that developing age-appropriate competence in the home language depends also on minority-language children's reactions to parental home language maintenance efforts. Minority-language children can challenge their parents' language rules and consequently play a significant role in deciding the home language in their families (Alsahafi, 2015; Tuominen, 1999). While children's attitudes may indicate the effectiveness of their families' home language maintenance efforts (Schwartz, 2008), such attitudes potentially influence children's linguistic behavior as well as their reactions to their parents' language maintenance strategies adopted at the family and community levels.

\section{References}

Allard, R., \& Landry, R. (1992). Ethnolinguistic vitality beliefs and language maintenance and loss. In W. Fase, K. Jaspaert \& S. Kroon (Eds.), Maintenance and loss of minority languages (pp. 171-195). Amsterdam: Benjamins. https://doi.org/10.1075/sibil.1.14all

Alsahafi, M. (2015). The role of Arab fathers in heritage language maintenance in New Zealand. International 
The attitudes of bilingual Arab immigrant children to their languages

Journal of English Linguistics, 5(1), 73-83. Retrieved from http://dx.doi.org/10.5539/ijel.v5n1p73

Alsahafi, M. (2018). Pluricentricity and heritage language maintenance of Arab immigrants in the English speaking New World countries. International Journal of Research Studies in Language Learning, 7(2), 39-102. Retrieved from https://doi.org/10.5861/ijrsll.2017.1795

Atkinson, D. (2000). Minoritisation, identity and ethnolinguistic vitality in Catalonia. Journal of Multilingual and Multicultural Development, 21, 185-197. https://doi.org/10.1080/01434630008666400

Baker, C. (1992). Attitudes and Languages. Clevedon: Multilingual Matters.

Baker, C. (2006). Foundations of bilingual education and bilingualism (4th ed.). Clevedon: Multilingual Matters.

Barkhuizen, G. (2006). Immigrant parents' perceptions of their children's language practices: Afrikaans speakers living in New Zealand. Language Awareness, 15, 63-79. https://doi.org/10.1080/09658410608668851

Bialystok, E. (2001). Bilingualism in development: Language, literacy, and cognition. New York: Cambridge University Press. https://doi.org/10.1017/CBO9780511605963

Borland, H. (2006). Intergenerational language transmission in an established Australian migrant community: What makes the difference? International Journal of the Sociology of Language, 180, 23-41. https://doi.org/10.1515/IJSL.2006.038

Bourhis, R. Y., Giles, H., \& Rosenthal, D. (1981). Notes on the construction of a 'subjective vitality questionnaire' for ethnolinguistic groups. Journal of Multilingual and Multicultural Development, 2, 145-155. https://doi.org/10.1080/01434632.1981.9994047

Budiyana, Y. E. (2017). Students' Parents' Attitudes towards Chinese Heritage Language Maintenance. Theory and Practice in Language Studies, 7(3), 195-200. Retrieved from http://dx.doi.org/10.17507/tpls.0703.05

Chase, S. E. (1995). Taking narrative seriously: Consequences for method and theory in interview studies. In R. Josselson \& A. Lieblich (Eds.), Interpreting experience: The narrative study of lives (pp. 1-26). Thousand Oaks, CA: Sage.

Choi, J. K. (2003). Language attitudes and the future of bilingualism: The case of Paraguay. International Journal of Bilingual Education and Bilingualism, 6(2), 281-94. https://doi.org/10.1080/13670050308667774

Clyne, M. (2003). Dynamics of language contact. Cambridge: Cambridge University Press. https://doi.org/10.1017/CBO9780511606526

Clyne, M., \& Kipp, S. (1999). Pluricentric languages in an immigrant context: Spanish, Arabic and Chinese. Berlin/New York: Mouton de Gruyter. https://doi.org/10.1515/9783110805444

Crystal, D. (1992). An encyclopedic dictionary of language and languages. Cambridge, MA: Blackwell.

Cummins, J. (1996). Negotiating identities: Education for empowerment in a diverse society. Ontario: California Association for Bilingual Education.

De Houwer, A. (1998). Environmental factors in early bilingual development: The role of parental beliefs and attitudes. In G. Extra \& L. Verhoeven (Eds.), Bilingualism and migration (pp. 75-96). New York: Mouton de Gruyter.

Fillmore, L. W. (2000). Loss of family languages: Should educators be concerned? Theory into Practice, 39 , 203-210.

Fishman, J. A. (1972). The sociology of language. Rowley, MA: Newbury House.

Fishman, J. A. (1989). Language and ethnicity in minority sociolinguistic perspective. Clevedon: Multilingual Matters.

Fishman, J. A. (1991). Reversing language shift. Clevedon: Multilingual Matters.

García, M. (2003). Recent research on language maintenance. Annual Review of Applied Linguistics, 23, 22-43. https://doi.org/10.1017/S0267190503000175

Gibbons, J., \& Ramirez, E. (2004). Maintaining a minority language: A case study of Hispanic teenagers. Clevedon: Multilingual Matters.

Giles, H. (1973). Accent mobility: A model and some data. Anthropological Linguistics, 15, 87-105.

Giles, H., Bourhis, R. Y., \& Taylor, D. M. (1977). Towards a theory of language in ethnic group relations. In H. 
Alsahafi, M.

Giles (Ed.), Language, ethnicity and intergroup relations (pp. 307-348). New York: Academic Press.

Holmes, J., Roberts, M., Verivaki, M., \& 'Aipolo, A. (1993). Language maintenance and shift in three New Zealand speech communities. Applied Linguistics, 14, 1-24. https://doi.org/10.1093/applin/14.1.1

Hult, F. M., \& Hornberger, N. H. (2016). Revisiting orientations in language planning: Problem, right, and resource as an analytical heuristic. Bilingual Review/Revista Bilingüe, 33(3), 30-50. Retrieved from http://bilingualreview.utsa.edu/index.php/br/article/view/118/84

Miles, M. B., \& Huberman, A. M. (1994). Qualitative data analysis: A sourcebook of new methods (2nd ed.). Newbury, CA: Sage.

Myers-Scotton, C. (2006). Multiple voices: An introduction to bilingualism. Malden, MA: Blackwell.

Nagpal, N. \& Nicoladis, E. (2010). Positive attitudes are not enough: Minority language survival in the Canadian Prairies. Journal of Intercultural Communication, 24. Retrieved from http://www.immi.se/intercultural/

Nguyen, T. \& Hamid, M. (2016). Language attitudes, identity and L1 maintenance: A qualitative study of Vietnamese ethnic minority students. System, 61, 87-97. https://doi.org/10.1016/j.system.2016.08.003

Pauwels, A. (2004). Language maintenance. In A. Davies, \& C. Elder (Eds.), Handbook of Applied Linguistics (Vol. 1, pp. 719-737). Cambridge: Blackwell. https://doi.org/10.1002/9780470757000.ch29

Ruiz, R. (1984). Orientations in language planning. Journal of the National Association for Bilingual Education, 8(2), 15-34. https://doi.org/10.1080/08855072.1984.10668464

Ryding, K. C. (2005). A reference grammar of modern standard Arabic. Cambridge: Cambridge University Press. https://doi.org/10.1017/CBO9780511486975

Schwartz, M. (2008). Exploring the relationship between family language policy and heritage language knowledge among second generation Russian-Jewish immigrants in Israel. Journal of Multilingual and Multicultural Development, 29, 400-419. https://doi.org/10.1080/01434630802147916

Statistics New Zealand. (2013). New Zealand census of population and dwellings: Language spoken (Total responses). Retrieved from http://www.stats.govt.nz

Taft, R., \& Cahill, D. (1989). Mother tongue maintenance in Lebanese immigrant families in Australia. Journal of Multilingual and Multicultural Development, 10, 129-143. https://doi.org/10.1080/01434632.1989.9994369

Tajfel, H. (1974). Social identity and intergroup behaviour. Social Science Information, 13, 65-93. https://doi.org/10.1177/053901847401300204

Tannenbaum, M., \& Howie, P. (2002). The association between language maintenance and family relations: Chinese immigrant children in Australia. Journal of Multilingual and Multicultural Development, 23, 408-424. https://doi.org/10.1080/01434630208666477

Tuominen, A. (1999). Who decides the home language? A look at multilingual families. International Journal of the Sociology of Language, 140, 59-76. https://doi.org/10.1515/ijsl.1999.140.59

Yagmur, K., \& Kroon, S. (2006). Objective and subjective data on Altai and Kazakh ethnolinguistic vitality in the Russian Federation Republic of Altai. Journal of Multilingual and Multicultural Development, 27, 241-258. https://doi.org/10.1080/01434630608668778

Zhang, D. (2004). Home language maintenance among second-generation Chinese American families. Working Papers in Educational Linguistics, 19, 33-53. 